\title{
Kurt Nyberg
}

\section{ALBERTI OM MÅLARKONST \& FLYKTPUNKTER}

\section{ALBERTIS TRAKTAT OM MÅLARKONSTEN P̊ SVENSKA}

Leon Battista Albertis klassiska traktat Om målarkonsten från 1430-talet har utkommit i svensk språkdräkt. ${ }^{1}$ Översättaren, konstnären Sölve Olsson, har gjort sig känd som en flitig skribent om perspektivteoretiska frågor. Ilan har tidigare översatt ett par av perspektivteorins klassiska essäer; Erwin Panofskys Perspektivet som symbolisk form 1994, och Maurice Merleau-Pontys "Ögat och tanken" i Res Publica 12/13, 1989.2 Texterna är återgivna på en påfallande god svenska och fungerar väl som introdulktioner till intressanta tänkare.

Detsamma gäller översättningen av Om målarkonsten. Den motsvarar rimligt ställda krav på exakthet, och de perspelztivtekniskt svåra partierna är briljant genomförda. Olsson har försett texten med genomtänkta figurer som öppnar för närmare läsning även för den som känner Albertis text väl på något annat språk. Den som har möjlighet att parallellt fördjupa sig i Cecil Graysons kritiska utgåva av texten på latin och italienska kan troligen vinna mycket på att använda detta nya hjälpmedel. ${ }^{3}$ Som första möte med denna klassiker kan Olssons översättning fungera utmärkt, möjligen skulle den i framtiden kunna förses med ett bihang av anmärkningar, ägnade att ge texten dess kulturhistoriska placering och kommentera de val som översättaren gjort i komplicerade fall. Detta skulle vara lätt att ordna eftersom Olssons svenska översättning, liksom för övrigt de senaste engelska och franska, använder sig av den paragrafindelning som Grayson införde i den kritiska utgåvan frăn 1973.

1 Leon Battista Alberti, Onn målarkonsten, övers. Sölve Olsson (Stockholm: Symposium, 1996).

2 Erwin Panofsky, Perspektivet som symbolisk form, övers. Sölve Olsson (Stockholm: Symposium 1994).

3 Leon Battista Alberti, De Pictura, Opere Volgari, volume terzo, Trattati d'Arte, Lucli reram Matbemnaticarnum, Gramnnatica della Linngua Toscana, Opuscoli Anatori, Lettere, a cura di Cecil Grayson, (Bari: Guis. Laterza \& Figli, 1973) 
I förordet kommenterar översättaren det märkliga faktum att Albertis text var praktiskt taget okänd för eleverna på Konsthögskolan under 50-talet. Då var det Cennino Cenninis Boken om mälarkonsten som dominerade. "Alberti nämndes aldrig, varken oss elever emellan, i undervisningen eller i konstdebatten." Lite senare fortsätter han:

De konventioner som styr både akademier och fria konstskolor sållar i det tysta fram vad som för tillfället är - och inte är - "estetiskt korrekt". Därför var Alberti okänd för och osynliggjord för oss. Vi skulle troligen föraktat Alberti - om vi känt till hans existens. Vi kanske skulle förkastat hans argument - om vi läst hans bok. Men vi skulle säkert vunnit på att lära känna en så kvalificerad meningsmotståndare. ${ }^{4}$

Boken är kort och översättarens kommentarer är få, förordet omfattar lite mer än fyra sidor och en bibliografi i slutet upptar bara ett fåtal titlar. Lika kortfattad som utmärkt är översättarens resumé som anger det intressantaste i varje paragraf i rubrikform; här finns gott om plats för egna anteclaningar. I det följande svarar jag på översättarens utmaning och försöker mig på en kritisk läsning av den första delen, där Alberti lägger den teoretiska grunden för det nya perspektivet. Min undersökning utgör ett inlägg i en debatt som har sin utgångspunlkt i Sölve Olssons reaktion på några detaljer i en artikel av Marianne Marcussen publicerad i Nordisk Estetisk Tidskrift 11, 1994.5

\section{ETT KARNEVALISKT ELEMENT I ALBERTIS TRAKTAT OM MÅLARKONSTEN}

Jag har intresserat mig för ett karnevalistiskt element $i$ Albertis traktat om måleriet. Finns det inte, frågar jag mig, ironiska poänger dolda i de passager som moderna uttolkare karaktäriserat som svagheter i tankegången? Kanske skall texten läsas som en spelplan för retoriska möjligheter. Det finns forskare som antyder denna möjlighet. ${ }^{6}$ Ibland kan det förefalla som om Alberti behandlar sin antike föregångare Vitruvius med saturnaliska gester; jag tänker framför allt på passagen där Alberti argumenterar för att använda en kroppsdel

4 Alberti, Om mailarkonsten, vii.

5 Marianne Marcussen, "Kunsthistorien, virkeligheden, perspektivrummet - og Norman Bryson", Nordisk Estetisk Tidskrift, 1994, No. 11, 23-42.

6 Anthony Grafton, "Panofsky, Alberti, and the Ancient World" i Meaning in the Visual Arts: Views from the Outside (A Centennial Commemoration of Erwin Panofsky), ed. Irwing Lavin (Princeton: Institute for Advanced Study, 1995) 123ff. Bland annat erinrar författaren här om att Alberti skrivit en satirisk hyllning till flugan. 
som måttenhet för att fånga kroppens proportioner. Så här lyder texten i Sölve Olssons svenska översättning:

Arkitekten Vitruvius använde människans fot som enhet när han. mätte kroppslängden: Jag tror det är mera värdigt att använda huvudets höjd som måttenhet trots att jag funnit att fotens längd hos de flesta människor motsvarar avståndet mellan haka och hjässa. ${ }^{7}$

En annan översättning återger samma avsnitt så här:

Arkitekten Vitruvius mäter människornas längd i fötter. Jag tycker dock att det är värdigare att använda sig av huvudet, eftersom jag har observerat att måtten på en människas fot är det samma som huvudets, från hakan till nacken. ${ }^{8}$

Albertis text har här fått helt olika utformning. Men den detalj som kanske är mest stötande i den senare versionen, att huvudets mäts från hakan till nacken, tycks vara en helt korrekt översättning. Skillnaden i formulering grundar sig här på att översättaren utgår från den första tryckta italienskspråkiga versionen av Albertis traktat, vilken utkom i Venedig 1547 under titeln La Pittura. Denna utgåva är en översättning från Albertis latinska version och i vissa avseenden "förbättrad" av översättaren Lodovico Domenichi. 9

De olika uppfattningarna om hur huvudets mått skall avgränsas kan föras tillbaka på Albertis egna texter i Graysons kritiska utgåva. "Cocuzzolo" i den italienska versionen motsvarar "hjässan" i svensk översättning, medan den latinska termen "cervicem" hos Alberti, i Domenichis italienska översättning ersätts av "collotola", som motsvarar "nacken" i den svenska versionen. ${ }^{10}$ Det verkar med andra ord som om Albertis italienska version talar om huvudets höjd medan den latinska tar ett mått som är vinkelrätt mot det förra. I Olssons översättning har ordet "höjd" smugit sig in av misstag. Alberti skriver om "al capo" utan vidare bestämning, eller på latin; "ad quantitatem capitis".

Passagen är märklig så till vida att varken de engelska översättarna Grayson respelative Spencer, eller Olsson kommenterar skillnaden mellan den italienska och den latinska texten, men den ter sig en smula egenartad även i ett annat avseende. ${ }^{11}$ Man kan fråga sig varför det skulle vara värdigare att mäta

7 Alberti, Om mailarkonsten, $\$ 36,48 f$.

8 Alberti, "Den andra Boken", Cennino Cennini, Leon Battista Alberti och Leonardo da Vinci, Traktater om Måleriet, (Uppsala: Institutionen för estetik, 1995), 54. Forni1 988

${ }^{9}$ Alberti, La Pittura, Traduzione di Lodovico Domenichi (Venezia, 1547) Faksimil,

10. Alberti La Pittura v 27, De Pictura \$36.

11 Leon Battista Alberti, On Painting, translated by Cecil Grayson, with an Introduction and Notes by Martin Kemp, (Harmondsworth: Penguin, 1991), \$36, och On Painting, translated with Introduction and Notes by John R. Spencer (New Haven/London: Yale Univ. Press 1966), 73. 
könsdelar och fötter med huvudet som mått, än det skulle vara att använda fötter.

Har inte den här sammanställningen av huvud och fot en satirisk kvalitet? Det är ganska drastiskt att mäta kroppen med fötterna, men det är väl inte bättre att använda huvudet för detta ändamål? Så, vad är han ute efter egentligen, Alberti? Vill han göra narr av sin store föregångare? Om det skulle vara fallet, så skulle vissa konnotationer av "cervix" aktualiseras, där termen kopplas till djärvhet och bärandet.av. ett ok. Alberti placerar sin nacke under Vitruvius fot $\mathrm{i}$ en saturnalisk gest för att frambesvärja solens återfödelse. Tolkningen har en viss dragningskraft, men en sådan tanke måste avfärdas som fullgod förklaring. Det finns en viktig aspekt på passagen som lyfts fram av oppositionen hjässa/nacke. Hakan blir i detta fall mötespunkten för två lika långa vinkelräta linjer, medan hjässans och nackens bågar bildar segment av en cirkel till hälften inskriven i en kvadrat som lätt lăter sig fullbordas. Bilden kan också framställas så att bara halkpartiet markeras som en liten kvadrat med ett hörn i cirkelns mittpunkt.

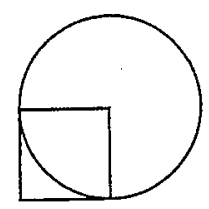

Figur 1

Låt oss nu jämföra denna figur med en fot. En cirkel och en kvadrat tycks vara enklare och mera fullbordade former än fotens häl valv och tår. Foten har å andra sidan en början en mitt och ett slut, där huvudets form har en kontinuerlig övergång från hjässa till nacke. Fotens mått är avslutat och entydigt på ett sätt som huvudets inte. är. Det är som om två stora principer ställdes emot varandra. Jag skall bli riktigt konkret och berätta en historia ur livet:

En dag stötte jag på en spelman som stod och fiddlade på gågatan i Uppsala. Det var en egenartad stråkmusik han framförde på sitt enkla estniska instrument. Han var klädd som en medeltida lekare i en grön och en röd hosa.

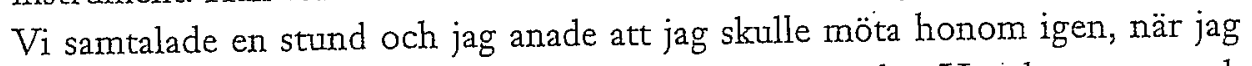
gick till en liten. fest med buskspel senare samma vecka. Han kom sent och spelade några låtar på mandolin innan fiddlan kom fram. Där var också några vänner till honom och de började diskutera vad de skulle spela. En polska föreslog fiddlaren, men då måste man stampa med foten för att takten skall bli 
den rätta. Repliken hade uppenbarligen en bestämd mottagare för en man med fiol svarade genast att han vägrade stampa i kväll. - I så fall kan jag inte lära dej att spela polska, då får det vara, sade den förste. Fiolspelaren vände sig därvid till mig och urskuldade sig genom att förklara att han spelat klassisk fiol i många år och det kunde han göra med huvudet, faktiskt var inget stampande tillåtet $i$ dessa sammanhang. Då rann det mig i sinnet vilken radikal gest det var av Alberti att ersätta Vitruvius fot med sitt huvud, och jag kände mig trungen att avbryta musiken en stund för att berätta om min fundering. Det var inte utan att spelmännen hade en del att säga som stödde min hypotes. Var det inte också vid renässansen som musiken tog ett avgörande steg från enkel oktavgång till symfoni? En historisł tablå målades kring denna tanke.

Längre än så för oss inte detta interludium. Vi har fătt utpekat att den Vitruviska foten var behändigt inlemmad i musikteorin som rytmisk enhet, och att renässansen innebar ett brott mot flera traditionella värden inom konsten. Jag tror att Albertis traktat kan läsas med oppositionen fot/huvud tolkad som en opposition mellan det distinkta och det kontinuerliga. En del av textens exempel får en intressant belysning med denna läsning. Sålunda utvecklas förståelsen av termen "braccio", som Olsson har översatt med "aln".12 Det slog mig att "braccio" i den italienska versionen har en viss släktskap med det italienska uttrycket för "omfamnande" i slutet på $\$ 18$; i den venetianska versionen av texten "abraciuano" motsvarande "misuravano" i Graysons italienska version. ${ }^{13}$ En braccia är också ca en tredjedels famn, nästan måttet på diametern till den cirkel som famnen famnar om. I den venetianska språkdräkten framhävs ett samband som finns, och framstår som ett retoriskt grepp i Albertis egen text. Först låter Alberti på tal om jämförelsens makt några satyrer $i$ en antik målning omfamna tummen på en cyklop "så att den sovande /jätten/ verkligen tycktes mycket stor-i.förhållande till satyrerna". ${ }^{14}$ Lite senare introducerar han sin delning av människokroppens längd "i tre lika delar vilka motsvarar det mått som kallas aln ("braccio")". Olson utvecklar i en not valet av "aln" som översättning av "braccio", båda orden betyder "underarm" och utgör måttenheter med ungefär samma längd. ${ }^{15}$ Man kan tillägga att en aln också utgör en tredjedels famn, i svenskan använt som både längd och rymdmått. Alberti använder braccian för att dela in nederkanten av tavlans rektangel och skapar med denna utgångspunkt i tavlan uppdelningen av en golvyta vars

12 Alberti, Om målarkonsten, 19.

13 Alberti, La Pittura, v 15.

14 Alberti, Om mailarkonsten, \$18.

15 Ibid., 26. 
flyktlinjer möts i "centrumpunkten". För att därefter finna läget på linjer parallella med bildens yta, som indelar golvet $\mathrm{i}$ kvadratiska rutor använder Alberti en metod som han kontrasterar mot ett algebraiskt system, där avståndet mellan de parallella linjerna för varje steg minskas med en tredjedel av föregående mått. Albertis metod är i stället geometrisk, han ritar upp en linje som motsvarar grundplanet i ett tvärsnitt av tavlans djupdimension på ett bräde och delar in denna linje på motsvarande sätt som tavlans nederkant tidigare delats. Vidare markeras ögonpunkten och från denna dras linjer till grundlinjens delningspunkter. På en linje vinkelrät mot grundlinjen kommer grundlinjens indelning att avtecknas som skärningspunkterna för linjer i strålknippet mellan grundlinje och ögonpunkt. Alberti visar hur detta geometriska tillvägagångssätt gör det möjligt att avsätta grundplanets parallella linjer på tavlan varefter en rät linje kan dras genom golvets rutmönster șa att hörnen på kvadraterna förenas, bilden bringas till en bättre överensstämmelse med naturen. Den äldre metoden som Alberti kallar "superbipartiens" ger harmoniska intervall mellan golvytans med tavlan parallella linjer, men här blir likheten med förebilden lidande $i$ det avseendet att diagonalerna mellan rutornas hörn inte bildar räta linjer. 16

Det är således ett centralt tema i Albertis traktat att kontrastera måleriets geometriska villkor med harmonilärans krav på rationellt jämförbara proportioner. Möjligen kan man tala om en revolution i detta sammanhang, men oppositionen mellan geometri och algebra är så gammal och så ofta uppställd att det verkar rimligare att se det som en saturnalisk gest.

Mitt förslag är att man skall läsa Albertis försvar för måleriets naturtrohet som en kontrast till Ptolemaeus harmonilära. Ptolemaeus jämställer regnbågens kontinuerliga spektrum med vargens ylande och menar att där inga bestämda toner förekommer går det inte att tala om harmoni. Harmoni definieras som relationer mellan tal: 1:2 uttrycker olktavens proportion, 2:3 motsvarar kvintförhållandet och så vidare. ${ }^{17}$ Den rena matematiken befinner sig på ett högre plan än geometrin, och den geometri som Alberti tillämpar har sina rötter djupt $i$ en medeltida praxis. Blott genom att ödmjuka sig inför lantmätarkonsten kan måleriet finna ny livskraft och liksom i antiken komma att väcka sådan högaktning att "konstnären ser sina verk tillbedda och känner sig själv vara nästan som en gud". Sedan lyftes läsaren av Albertis traktat på

16 Ibid., $\$ 18-20$.

17 Claudius Ptolemaeus, Ptolemaios und Porphyrios iiber die Musik, ty. övers. Ingemar Düring, Göteborgs högskolas årsskrift 1934:1 (Göteborg: Wettergren \& Kerner, 1934) $28 f$. 
några få sidor från det mödosamma trälandet med geometriska läxor till extasens höjder: "Är inte måleriet den förnämsta av alla konster eller dess främsta prydnad?" Så heter det i inledningen till andra boken. Men här skall jag inte fördjupa mig, utan jag skall låta den första boken komma i centrum.

Vi har talat om cirklar i flera olika klädnader; skallen blir i Albertis två olika versioner av jämförelsen med foten möjlig att konstruera som en cirkel, där hakan utgör ett hörn på en omskrivande kvadrat. Braccian blir diametern genom en cirkel. Likt satyrerna som omfamnar jättens tumme har vi nöjt oss med att försöka omfatta mycket små delar av Albertis traktat.

\section{OM ATT URSKILJA TVÅ SIDOR AV SEENDET MED HJÄLP AV ALBERTIS DISTINKTION MELLAN "VISA" OCH "PROSPECTAE"}

Jag skall fortsätta med ytterligare några detaljundersökningar, som fokuserar översättningens svårigheter. Inledningsvis skall jag behandla en passage där Olssons översättning blir lite väl abstrakt jämfört med originalet.

I slutet av $\$ 15$ skriver han: "Så står det klart att varje snitt genom synpyramiden parallellt med en yta är proportionellt till denna yta." Första gången termen "yta" förekommer i översättningen finner jag i den italienska texten uttrycket "alla veduta superficie" och där uttrycket "denna yta" förekommer finner jag i ursprungstexten "quella guardata superficie". $18 \mathrm{I}$ anslutning till Richard Tobins diskussion om en distinktion i Euklides optik, mellan de grekiska termerna "ORATAI" och "FAINETAI" villket motsvarar en skillnad mellan det sedda och uppfattningen av detsamma, kan jag tänka mig att göra samma distinktion i Albertis text. Det är Tobin själv som menar att en sådan undersökning är värd att göra eftersom Alberti kan förmodas ha blivit påverkad av den korrektare versionen av Euklides optik som användes före 1400-talet. En senare använd översättning baseras på en delvis urvattnad version som traderats via Theon av Alexandria. I Tobins läsning av Euklides ingår distinktionen $i$ ett försök att påvisa att Panofsky, i essän Perspektivet som symbolisk form, kommit att dra felaktiga slutsatser om förekomsten av ett antikt perspektiviskt framställningssätt, för att han utgått från Theons urvattnade version. 19

18 Alberti, De Pictura. La Pittura har istället "la superficie veduta" respektive 'quella superficie' considerata', ז 13.

19 Richard Tobin, "Ancient Perspective and Euclid's 'Optics', Foumal of the Warburg and Courtauld Institutes, 1990:53, n 27. 
Distinktionens form i Albertis traktat tycks verkligen vara likartad. Den latinska versionen ställer här "visa" mot "prospectae", alltså ett begrepp som täcker en syn eller en drömbild mot ett begrepp som handlar om en utsikt eller vy. Här har Spencer i sin engelska version gjort en tydlig skillnad, medan Grayson tycks ha bortsett från problemet. ${ }^{20} \mathrm{Om}$ vi upprepar den aktuella satsen och sätter in distinktionen kommer den att lyda så här: "Så står det klart att varje snitt genom synpyramiden parallellt med /utsiktens/ yta är proportionellt till denna /uppfattade/ yta." Det svåra med denna sats är inte språkligt betingat utan begreppsligt. Till det tänkta snittet genom synpyramiden läggs ett snitt av helt annat slag; den logiska skillnaden mellan det sedda och uppfattningen om detsamma:-Detta är en-klyvning som ställt till problem för filosofer, från Platon till Merleau-Ponty, och dess förekomst hos Alberti är generande för Norman Bryson och de av hans kollegor som dramatiserar en historisk utveckling kring perspektivet. ${ }^{21}$ Borde det inte vara Descartes som för in denna klywning mellan fenomenvärld och verklighet?

Som vi sett tycks Albertis stil vara impregnerad av dubbeltydigheter, och vi har ingen anledning att ställa oss främmande inför tanken att det i samma sats skulle kunna talas om snitt $i$ helt olika meningar, vilka ställer till trubbel för såväl uttolkare som översättare. Den distinktion som diskuteras här är dock en smula perifer när det gäller att framställa och diskutera linjeperspektivets villkor i Albertis text. Jag ser ingen enkel lösning på översättningsproblemet, men jag tycker att "yta" är mer abstrakt och tekniskt än de uttryck termen ersätter. Jag har också den känslan att det är åt det hållet Olsson vill driva tolkningen. Jag tänker på kommentaren i förordet där han skriver: "Alberti har inte lyckats dölja denna intressekonflikt och inte heller att verket kommit till under en viss brådska med oklarbeter och motsägelser som foljd."22 Jag har velat peka ut att de oklarheter som förekommer i Albertis resonemang är så pass viktiga och djupgående att de inte alls behöver vara resultatet av en brådska. Likaväl som misstag kan de vara accepterade paradoxala inslag i texten, vilka utgör de pådrivande momenten i tolkningsprocessen.

20 Alberti, Om målarkonsten, $53 \mathrm{f}$.

21 Norman Bryson, Vision and Painting: Logic of the Gaze, (London: Macmillan, 1983) 94 och $102 \mathrm{ff.}$ 'Seen' och 'observed', Spencers översättning, tycks täcka skillnaden mellan det ögonblickliga intrycket och det närmare betraktandet, som motsvarar skillnaden mellan 'glance' och 'gaze' hos Bryson. Dennes uppfattning är "that Alberti's conception of the subject is already Cartesian". Men om idén att anknyta till Tobin håller är Albertis uppfattning grundad i den medeltida optiken, och går att föra tillbaka till antiken, så vad gör 'already' för något i Brysons historieskrivning?

22 Alberti, Om, mâlarkonsten, VIII. 


\section{OM "CENTRUMSTRÅLE" OCH "HORISONT"}

Alberti använder såvitt jag kan finna begreppet "centrumstråle" på två olika sätt, dels om en stråle som motsvarar normalen mot en yta, och dels om den centrala strålen som är normalen mot genomskärningen av synpyramiden. Den förra användningen tycks mig orimlig, men viktig i Albertis retoriska modell.

Så här gör Alberti enligt min mening: 1) I slutet av $\$ 2$ presenterar han "centrumlinjen" motsvarande diametern $i$ en cirkel. 2) Tre olika sorters synstrålar definieras; "ytterstrålar" villka möter ytans konturer, "mellanstrålar" som fyller synpyramiden, av vilka en kallas "centrumstråle, så som jag nyss talade om centrumlinjen. Centrumstrålen möter ytan på ett sådant sätt att den bildar räta vinklar på alla sidor".23 3) Synpyramiden behandlas utförligare i $\$ 7$ : "Pyramidens bas är den yta vi ser, dess sidor de synstrålar vi kallar ytterstrålar". Sedan definieras i $\$ 8$ centrumstrålen som "den enda som träffar kvantiteten på ett sådant sätt att vinklarna på ömse sidor är lika" varefter det hela kulminerar; "denna stråle stöds av alla de omgivande strålarna och är den sista som lämnar det betraktade föremålet och därför förtjänar den att kallas ledaren och fursten bland strålar."

Denna retoriska figur förlägger den centrala synstrålen till mitten av en cirkel, kardinalpunkten, mittpunkten, hjärtpunkten eller vad man vill kalla den, kanske en smickrande gest mot maktens män som hämtat sina titlar från olika benämningar av denna medelpunkt. Samtidigt blottar Albertis resonemang om olika ytors form i $\$ 4$ en paradoxal trohet mot en annan princip. I en konvex eller sammansatt yta kan under vissa omständigheter fler än en stråle möta planet "på ett sådant sätt att den bildar räta vinklar på alla sidor". Men när allt kommer omkring är Albertis resonemang avsiktligt förenklat och allt han vill påvisa är att: "om avståndet eller centrumstrålens läge ändras så ter sig också ytan förändrad".24 Min fundering runt detta tema făr mig att försöka gestalta alla dessa plan, eller några av dem, med var sin synpyramid, sådan att den centrala synstrålen träffar planet vinkelrätt. Jag ser för mitt inre öga en värld där ytor visar sin synlighet som synpramider i alla upptänkliga riktningar. Denna värld liknar den bysantinska bildvärlden. Jag tänker särskilt på solstrålarna i bilden av Johannes frăn 1300-talets Konstantinopel. Är alltså

23 Ibid., i slutet av $\$ 5$.

24 Ibid., $\$ 8$. 
Albertis utgångspunkt en variant av den gamla stilen? "Vi har sett hur de enskilda ytorna bildar var sin pyramid med egen färg och eget ljus" skriver Alberti i $\$ 12$. I målningen skall sedan pyramiderna som motsvarar en kropps alla synliga kvantiteter underordnas en blickpunkt och tavlans yta, vilken skall betraktas som vore den genomskinlig, motsvarande snittet genom synpyramiden.

Plötsligt känner jag mig säker. Här finns en förmedlande övergång mellan bysantiniserande stil och den nya stilen. Paradoxen som behandlas i resonemanget ovan är djup och varaktig, den har utgjort ett kritiskt moment $\mathrm{i}$ perspektivläran fram till våra dagar. I Albertis text är den något mer än en tillfällig-svårighet, den utgör i stället det centrum kring vilket hela framställningen kretsar.

När jag läste Olssons översättning mot den venetianska versionen jag hade tillgänglig hamnade jag tidigt i svårigheter. I $\$ 2$ fann jag att Olsson använder uttrycken "cirkelyta" respektive "yta" där den italienska texten har termen "prospettiva". ${ }^{25}$ Termen förekommer två gånger: a) där Olsson skriver: "Den ena känner vi som den kontur vilken omsluter en yta", och b) där han skriver: "En cirkellinje innesluter en cirkelyta" Jag har kursiverat de ord som i den venetianska texten översatts med "prospettiva". Grayson tycks i detta sammanhang konsekvent använda termen "surface". Om vi går till den latinska texten finner vi här en utvikning som Olsson intressant nog förlagt till $\$ 20$. Den latinska texten talar om bruket att kalla den omslutande linjen för "horisonten" men att han själv föredrar att använda det latinska ordet "fimbria", som översätts med "outline" respektive "kontur" i de engelska och svenska versionerna, men som har de lexikaliska betydelserna "mattfrans", respektive "de yttersta krusiga hårlockarna". Associationen till horisonten kan vara orsaken till att Domenichi lrommit att använda "prospettiva" för att beteckna den yta som innesluts av konturen. De svenska motsvarigheterna skulle här vara i ena fallet "synfältet" och "synkretsen" i det andra. Den korrekta översättningen av den senare passagen är dock Olssons: "En cirkelyta är det slags yta som omsluts av en linje som av en krans." Resonemanget handlar bara ytligt om stil och ordval, ty passagen är strategisk. Det är här Alberti förbereder introduktionen av "centrumlinjen". Det är den räta linje som skär cirkelns centrum och bildar räta vinklar där den möter cirkelns omkrets. "/O/ch låt oss acceptera här vad matematikerna påstår: att inga andra linjer bildar rät vinkel med cirkelns omkrets än de som går genom dess centrum". När senare i $₫ 5$

25 Alberti, La Pittura, $5 \mathrm{v}$. 
Alberti definierar den centrala synstrålen och kallar den "centrumstrålen" i analogi med centrumlinjen, så lyfter denna sammanlikning fram likheten med synkretsen som antytts i $\$ 2$. Centrumstrålen möter horisonten i rät vinkel, men horisonten är ju en rand som omsluter betraktarens synkrets och bildar en cirkel. För att göra det konkret kan vi dra in den sfäriska ytan från \$6 i jämförelsen. Här har Olsson illustrerat med en figur som utmärkt belyser förhållandena. Vi kan föreställa oss att jordklotet symboliseras av sfären och att ögonpunkten markerar olika betraktarpositioner, på marken eller uppe på ett högt berg som ger olika uppfattningar om jordens storlek. Detta kan te sig som en övertolkning, men den har sin motivering i $\$ 20$. I slutet av första boken återkommer nämligen "centrumlinjen"; nu i horisontlinjens roll. Rollbytet är i högsta grad märkvärdigt, dessutom är sammanhanget för dess placering tvetydigt i $\$ 20$, där texten lyder:

Denna linje betyder för mig en gräns bortom vilken ingen kvantitet kan ses om den inte befinner sig över betraktarens ögonhöjd. Eftersom linjen passerar genom centrumpunkten kallar jag den. "centrumlinjen" ("horisonten") 26 .

När jag läst detta och jämfört formuleringen med den latinska och italienska förlagan skriver jag till översättaren: ${ }^{27}$

Översättning verkar vara en kollektiv process, som hela tiden öppnar möjligheter till nya läsningar och stänger andra möjliga tolkningsvägar. I din översättning har jag funnit en oväntad öppning som verkar stämma bra med den venetianska upplagans tolkning. Jag har nu läst bolk 1 och hittat ytterligare några passager att fundera på. Framför allt har jag hittat "horisonten" i $\$ 20$, med din hänvisning till $\$ 2$ i noten. Detta förefaller mig egendomligt, nästan som en freudiansk felsägning, eftersom "horisonten" på detta ställe varken finns i min italienska upplaga eller i Graysons italiensk/latinska utgåva. Dessutom är din översättning av den föregående meningen helt annorlunda än Spencers och möjligen även Graysons. Jag tycker att din version är bättre: "Denna linje betyder för mig en gräns bortom vilken ingen kvantitet kan ses om den inte befinner sig över betraktarens ögonhöjd." Här är det klart att det är horisonten som avses, fjorton kilometer bort försvinner fartyget bakom horisonten. De engelska versionerna skulle väl haft "över" där du har valt "bortom," och möjligen är passagen återigen tvetydig på samma sätt som avsnittet $\mathrm{i}$ $\$ 2$ om horisonten.

För är det inte så att tillägget om terminologin $i$ den latinska versionen leder tankanna lika mycket till som från föreställningen om cirkelytans avgränsning som den verkliga horisonten. I din version är det som om du med hänvisningen till $\$ 2$ ville argumentera för din tolkning, och då är det ju lite otur att passagen om "horisonten" råkat falla bort. Samtidigt fungerar avvikelsen som en sorts markering, en svårighet som

${ }^{26}$ Alberti, Om mailarkonsten, 31.

27 Alberti, La Pittura, $17 \mathrm{r}$. 
kan leda till en mera dynamisk läsning av Albertis argument. Det är ju tydligt att översättaren i 1547 års Venedig antingen medvetet eller omedvetet såg och poängterade sambandet mellan italienskans "orizonte" och termen "prospettiva" som väl kanske här kan tolkas som det totala synfältet. Försvinnandet av en kvantitet bortom horisonten har ju också ett intimt samband med det fenomen som Alberti diskuterar i $\$ 6$ och som du illustrerar med "figur 4." I de engelska versionerna av $\$ 20$ har jag svårt att läsa in denna syftning, här făr passagen om "linea centrica" sin innebörd inom kyrkans begränsade rum, villket verkar vara mera av ett euklidiskt rum, där jordytans krölnning inte spelar någon roll. ${ }^{28}$

Det är väl här någonstans som vissa slutsatser kan dras angående svårigheterna att sätta sig in i renässansens perspektivbegrepp från vår vetenskapliga horisont. Jordytans krökning spelar in i såväl optikens som måleriets perspektivproblem, men tenderar att förbises i många moderna texter där författarna är angelägna om att se en utvecklingshistoria med det slutliga genombrottet för ett vetenskapligt perspektiv i och med 1600talets geometriska bevis. Detta är ett problem som Elkins tar upp och som är aktuellt i din diskussion med Marianne. ${ }^{29}$ Din översättning blir på detta sätt en smula kontroversiell, men jag är övertygad om att du har făngat en viktig poäng, när du talar om kvantiteters försvinnande bortom horisonten.

Hela Albertis teori om centralperspektivet är innesluten mellan $\$ 2$ och $\$ 20$, och liksom genomkorsad av ambivalensen i uttrycket "linea centrica". Jag har redogjort för hur Alberti introducerar synpyramiden, vilket är genomfört i $\$ 12$. Några paragrafer om färg, ljus och skugga som jag inte går närmare in på är insprängda mellan presentationen av centrumstrålen som synstrålarnas furste $i$ $\$ 8$ och den fullständiga behandlingen av synpyramiden i $\$ 12$. Dessa är i förbigående sagt ett passande centrum för texten eftersom färg och ljus är de viktigaste elementen i filosofisk optik sedan Aristoteles. Textens andra stora tema behandlar vinklar och proportioner, i synupplevelse och i måleri. Upptakten finns i $\$ 6$, men den utförligare diskussionen förs i $\$ 13-20$. Behandlingen av horisontella och vertikala ytor, parallella och kollineära, följs av diskussionen av proportionaliteten mellan snittet genom synpyramiden och

28 Hugh of St. Victor, Practical Geometry /Practica Geometriae, attributed to Hugh of St. Victor, translated from the Latin, with an Introduction, Notes and Appendices by Frederick A Homann, S. J. (Milwaukee: Marquett University Press, 1991): "This, [att himlasfären möter jordytan] of course, is not the case, but appears so, because straight sight lines cannot differentiate great distance."

"Our sight line terminates, in every direction, in a circle we call the horizon. Here, as noted, the celestial sphere itself seems joined with earth's surface. Horizon is "limit", because it limits the extent of our vision, and somehow prevents it from going farther. The horizon, then, is a circle bounding that part of earth's surface open to our wiew."

$234 \mathrm{ff}$.

29 James Elkins, The Poetics of Perspective (Ithaca/London: Cornell Univ. Press, 1994) 
den sedda ytans mått, vilken byggs upp från resonemanget om proportionerliga trianglar och generaliseras till att gälla synpyramiden. Sedan följer behandlingen av ytor som inte är parallella med målningens yta, där $\$ 17$ utgör en skicklig sammanfattning av kvalificerade matematiska problem, utformad så att de problem som kan aktualiseras i konstruktionen av linjeperspektivet illustreras i diskussionen av kvantiteter som förutom att vara parallella med målningens yta kan vara antingen kollineära eller parallella med synstrålarna. De kollineära avtecknas på bilden som en punkt, medan de parallella tar plats på snittet i proportion till storleken av den trubbiga vinkeln som bildas när kvantiteten görs till basen $i$ en triangel med spetsen $i$ ögonpunkten. Redovisningen av problemställningarna är påfallande fullständig. När sedan Alberti övergår till att redovisa hur han gör för att konstruera perspektivet i praktiken, så är samtliga lösningar väl förankrade i det tidigare resonemanget.

\section{Perspektivet, verkligheten och Marianne Marcussen}

Mot bakgrund av denna uppfattming har jag mycket svårt att följa Marianne Marcussens uppfattning om Albertis svårigheter med perspektivkonstruktionen. I en artikel från 1993 skriver hon:

the point at infinity, where the lines seems to meet, but will not do so in reality, is put as a point in the picture. But Alberti, who seems to accept this pictorial scheme or norm as given, is completely silent about his sources. ${ }^{30}$

Visserligen nämner Alberti inte några källor, men det förfaller inte heller nödvändigt, eftersom texten innehåller ganska fullständiga matematiska argument för att parallella linjer i synbilden strålar samman på stort avstånd i $\$ 6$ och att det utom linjer parallella med bildplanet bara finns linjer antingen kollineära eller parallella med någon av de strålar som utgår från ögat i $\$ 17$. Marcussen skriver vidare: "both Brunelleschi and Alberti must also, as mentioned, have established the concept of a picture plane and a station point. How this came about has not yet been established". 31 Hennes tes är att malleriet under senmedeltiden var påverkat av en romersk metod att låta flyktlinjerna definieras mot ett rutnät så att de olika flyktlinjernas lutning kan bestämmas som förhållanden mellan antal rutor i nätet. Denna vision av senantik

30 Marcussen, Marianne, "Space in Artistic Representation and Geometry", preprint til artikel der udkommer i kongresberetning til kongressen Il Disegno di Progetto dalle Origine atutto il XVIII secolo (Rom: La Sapienza, 1993), 13.

31 Ibid. 
perspektivtradition har mycket som talar för sig, bland annat att den låter sig kombineras med harmoniläran, men jag tror att Marcussen går för långt när hon förilarar att:

/the recessional triangle, as seen in the superbipartiens methods of depicting the recession in depth of lines lying horizontal and at right angles and of lines lying parallel to the picture plane could be, and in my opinion is, the artistic and mathematical source of perspective. ${ }^{32}$

Den ovan nämnda artikeln av Tobin anför möjligheten av att Euklides optik erbjöd en fullständig grund för perspektivisk avbildning, och jag tror att hans argument är lika giltigt mot Marcussens som mot Panofskys historieskrivning. Jag tror vidare att Albertis resonemang är optiskt och geometriskt grundat $i$ lantmäterikonst och skolastisk filosofi, och betydligt mer genomarbetat än Marcussen är beredd att tillstå. Hennes läsning av Alberti verkar otillräcklig, och det är i själva verket bakgrunden till att Sölve Olssons översättning av tralktaten Om målarkonsten blev fullbordad. Så här skrev Olsson till mig 28 januari 1995:

/...Nordisk Estetisk Tidskrift - 11/94. Där fanns en artikel av Marianne Marcussen som fick mig att formulera en invändning. Det inlägget tänkte jag mig få ihop på en dag, men det tog mig tillbaka in i ett gammalt aldrig genomfört projekt som nu grävdes fram ur hyllorna: en översättning till svenska av Albertis bok om målarkonsten. Marcussen skriver egentligen om Norman Bryson /.../men då kommer hon in på vad Alberti sagt och skrivit. Det var då som jag ryckte till - står det verkligen så? Jag hämtade den engelska översättningen av Grayson som MM hänvisar till och läste noga igenom, en gång flera gånger och satte mig sedan att skriva. Resultatet som jag sände till redaktionen för NET hoppas jag väl få publicerat där /.../ Omläsningen av Alberti fick ett annat resultat också: en revidering av min gamla handskrivna översättning, nu med tillgång till både en ny fransk och Albertis egen från latin till italienska /.../

Marcussens Alberticitat på sidan 34 i NET 11 är det som fångat Olssons uppmärksamhet.

Synsvinklen er $i$ öjet og toppunktet af synspyramiden ligeså, hvor synsvinklerne mödes og bebor öjet - og centralstrålen eller den centrale synstråle er den som rammer genstandene ved rette vinkler.

Det är inget riktigt citat utan snarare en sammanfattning, som kanske inte skulle betyda så mycket om Marcussen inte tyckts dra långtgående slutsatser från detta felaktiga citat. I nästa stycke skriver hon:

I den matematiske konstruktion må og skal genstandene stå vinkelret på den teoretiske synsretning, centralstrålen, ellers kan perspektivet, på Albertis tid, simpelthen ikke konstrueres.

32 Ibid., 12. 
Litet senare fortsätter resonemanget:

Det tog 200 år for matematikere at udvikle teorin om forsvindlingspunkter så rum placeret skaevt i forhold til billedplanet kunne konstrueres på relativt enkel måde. ${ }^{33}$

För att komma från en erfaren perspektivforskare är denna uppfattning förvånande, och Olsson formulerar sin kritik genom att hänvisa till Albertis text. Det första citatet här syftar på de tidiga paragraferna i första boken medan det andra resonemanget hör hemma i samband med Albertis framställning av perspektivet i en målning. Den paragraf som Olsson anför som motbevis till Marcussens är $\$ 17$, som han i översättningen försett med en väl genomtänkt figur. Det är ganska lätt att konstatera att Olssons figurer kan formas om så att figur 10 mer eller mindre motsvarar figur 15, (se: Figur 2) med peripendikeln ersatt av ett snitt vinklat så att det motsvarar målningens förhållande till blickens riktning där den är parallell med en linje i bildvärlden.

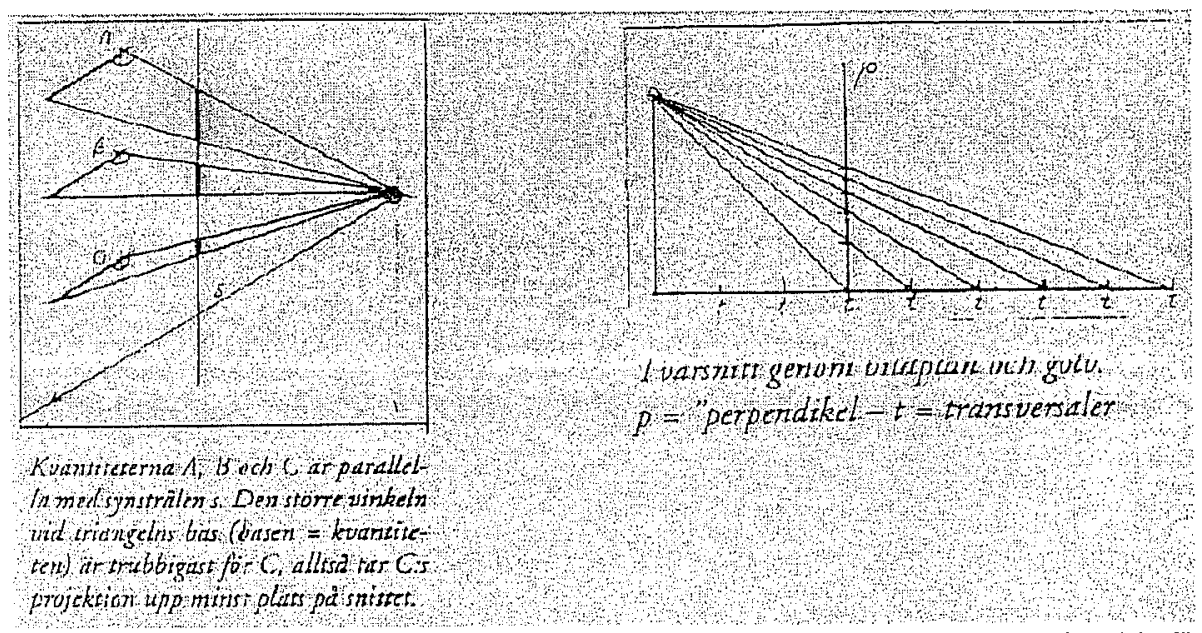

Figur 2

Jag har prövat att använda Alberti i undervisningen. Jag fick tillfälle att hălla en föreläsning om perspektivet och jag kunde bygga den på uppläsning och direktöversättning ur Grayson. Det fungerade utmärlkt. Jag gick inte in på de allra djupaste resonemangen, men arbetet med texten gjorde klart för mig att det skulle gå att driva resonemanget i $\$ 17$ och $\$ 19$ till enkla modeller för bestämning av valfria flyktpunkter. Albertis argument kan läsas i sin helhet, så

33 Marcussen, "Kunsthistorien, virkeligheden, perspektivrummet - og Norman Bryson", 23-42. 
att de utspridda delarna ger en alldeles tillfredsställande framställning av perspektivets matematiska villkor. Och den torde väl vara skriven för att läsas och diskuteras på ett sådant sätt att $\$ 19$ kan tillämpas på $\$ 17$.

För att återkomma till det historiska problemet med tidpunkten för uppkomsten av metoder att arbeta med flera olika flyktpunkter i samma perspelktiv, så har jag försökt finna ut vad andra perspektivforskare är beredda att tillerkänna Alberti i form av geometrisk förmåga. Jag fann en artikel av Kirsti Andersen i som berör dessa frågor.34 Det verkar inte som om hon är beredd att placera det matematiska beviset för perspelktivets riktighet före 1600 talet. Men samtidigt är analogierna mellan Albertis samlade argumentering och Gravesandes eller Lamberts bevis rätt slånde. Dessutom anmärker hon:

It is noticeable That this proof only uses arguments that can be deduced from Euclid"s Elements, book XI. This means that when several writers before 1600 were struggling with the problem of explaining how constructions of perspective images could be obtained from the mathematical model, the mathematics needed for solving this problem was available. However, the authors lacked the training to treat the problem. as a matbernatical exercise [min kursivering]. ${ }^{35}$

Inte heller John White i The Birth and Rebirth of Pictorial Space tycks vilja påstå att Alberti kände till distanspunktskonstruktionen. Det är en praxis han talar om, vilket inte utesluter att Alberti skulle kunna ha en bättre modell, men han tilltror inte Alberti någon fullständig förståelse av flyktpunktens teori. ${ }^{36}$

En matematikhistoriker som Morris Kline skriver i Matematiken $i$ den västerländska kulturen;

I själva verket var renässansmålarna ofullständiga i sin behandling av perspektivprinciperna. De slutgiltiga arbetena $i$ ämnet skrevs av en senare tids matematiker, främst Brook Taylor och I. H. Lambert. ${ }^{37}$

Decio Gioseffi i Encyclopedia of World Art, gör dock ingen särskild affär av det hela. ${ }^{38} \mathrm{Jag}$ tror att matematiker kanske läser perspektivtraktater på ett annat sätt än målare och konsthistoriker. Svagheterna i Albertis beskrivning av perspektivet hör verkligen till subtiliteterna i detta sammanhang, och det är väl

34 Kirsti Andersen, "Some observations concerning mathematician's treatment of perspective constructions in the 17 th and 18 th centuries", Mathemata, Festschrift für Helmut Gericke, ed. M. Folkerts \&U. Lindgren (Stuttgart: Franz Steiner 1984) 414.

35 Ibid.
36 John White, The Bintb and Rebirth of Pictorial Space (1957), rev ed. (London, Faber and Faber, 1987), $121 \mathrm{f}, 254$ : "Alberti himself had no full understanding of the nature of the vanishing point".

37 Morris Kline, Matematiken i den västerländska kultulren. (1958), övers. Jan Waldén (Stockholm: Prisma, 1968), 117. 1968).

38 Decio Gioseffi, "Perspective" i Encyclopedia of World Art (New York: Mc Graw-Hill, 
möjligt att det är matematikerna som tenderar att läsa fel, när argumenten inte är uppställda i en välkänd form. Kirsti Andersen är idéhistoriker med betoning på matematik. Hon har skrivit om Alberti också men jag har inte fått tag på den artikeln. Klines böcker tycker jag inte särskilt bra om. Han har en tendens att generalisera $\mathrm{i}$ onödan. Sammanfattningsvis verkar läsningarna av Alberti variera, delvis beroende på vilken sorts krav man ställer på ett bevis anses hans perspektivbeskrivning mer eller mindre tillfredsställande.

\section{ALBERTIS TEORI FÖR FLYKTPUNKTER I PERSPEKTIVBILDEN}

Jag är kanske skyldig läsaren en demonstration av Albertis flyktpunktsresonemang för att det skall bli alldeles tydligt att till exempel distanspunktmodellen kan betraktas som implicerad i Albertis text. Jag skall göra det så enkelt som möjligt, men grunda varje steg i Albertis egna påståenden. Från $\$ 20$ hämtar jag definitionen av en "parallell" är "avståndet leg. utrymmet/ mellan två linjer som i varje punkt befinner sig lika långt från varandra".39 De kvantiteter som mäter avståndet mellan parallella linjer är således lika i varje punkt. Med de yttre synstrålarna mäter ögat dessa kvantiteter "som med benen på en passare" finner vi i $\$ 6$, och kvantiteten bildar basen i en triangel med sin topp i ögat."

Eftersom synvinkeln finns i ögat kan man formulera följande regel: ju spetsigare vinkeln $i$ ögat är, dess mindre ses av kvantiteten. Därav förstår man varför en kvantitet på stort avstånd inte tycks vara större än en punkt. ${ }^{40}$

I $\$ 16$ talar Alberti om kvantiteter i bildrummet. Somliga är parallella med snittet och "dessa kvantiteter är i varje parallellt snitt proportionella: Därav följer att om de kvantiteter som bestämmer en kontur inte förändras, så

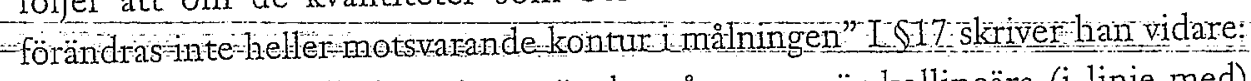
"Bland ické-parallella kvantiteter är det några som är kollineära (i linje med) synstrålarna, medan anđra löper parallellt med dem. "Det finns alltså bara dessa tre varianter; de som är parallella med snittet och avbildas proportionerligt med samma konturlinjer som i förebilden, de kollineära som

39 Alberti, Om målarkonsten, 30. Olsons översättning från latinet är här ej spärrad och en smula osäker. Alberti hänsvisar till att han behandlat saken utförligt tidigare, $\$ 13$ handlar om parallella ytor men även $\$ 6$ diskuterat hur parallalla linjer upplevs, medan den viktigaste syftningen torde vara till $\$ 17$. 'Avstånd' står här istället för latinets 'spatium' resp. engelskans 'space', någon verklig motsvarighet till dessa termer saknas i svenskan.

40 Ibid., $\$ 6$ s. $10 f$. 
"inte tar upp någon plats i snittet" (utgör en matematisk punkt) och de som löper parallellt med synstrălarna och som tar upp plats i snittet. De kvantiteter som inte är parallella med snittet men parallella med någon synstråle "förändras i samma grad som den större vinkeln i deras triangel är trubbig". (Fortfarande den triangel som har sin topp i ögat och där kvantiteten utgör basen.)

Detta menar jag är tillräckliga förutsättningar för att påvisa att linjer parallella med godtyckligt valda synstrålar löper samman mot en punkt i bilden där den valda synstrålen träffar densamma. Det räcker med att hänvisa till $\$ 6$ och konstatera att kvantiteterna mellan den valda synstrålen och dess paralleller i bildrummet är konstant, men i synintrycket "på stort avstånd inte tycks vara större än en punkt". Om vi nu i Olssons figur 10 tänker oss att kvantiteterna görs så stora att deras avstånd från den parallella synstrålen inte framträder som något annat än en punkt, så är alltså vinkelns trubbighet ett mått på mellanrummet mellan synstrålen och den parallella linjen, när det ter sig som störst.

Resonemanget kan tillämpas på särskilt utvalda synstrålar, som till exempel kan vara parallella med diagonalen mellan hörnen i bildvärldens kvadratiska golvplattor. En sådan synstråle skär en yta i bildens plan så att betraktarens avstånd till bilden är detsamma som avståndet mellan punkten där den centrala strålen träffar bildytan och motsvarande punkt för den valda synstrålen. Diagonaler i bildrummets golvmönster kommer att löpa samman mot denna punkt om de är parallella med samma synstråle. Det finns två distanspunkter på samma sätt som en kvadrat kan delas av en diagonal på två sätt. Men distanspunktkonstruktionen är långt ifrån alltid lätt att tillämpa, eftersom dessa punkter ofta hamnar utanför bilden så att, om denna är placerad på ett trångt ställe, det inte blir något utrymme för att sätta ut dessa punkter. Vid stafflimåleri torde problemet vara allmänt. Albertis metod har sålunda fördelar; den har visat sig mera generell än distanspunktskonstruktionen och den tillåter en målare att arbeta med andra flyktpunkter än distanspunkterna för att bestämma utläggningen av golvmönstret. Mot denna bakgrund är det svårt att läsa Albertis text som bristfällig i detta avseende. Brunelleschis pannå föreställande Baptisteriet i Florens torde också ha exemplifierat ett perspektiv där distanspunkterna dominerat. 


\section{Vitruvius, Alberti och Panofsky Beskriver FLYKTPUNKTENS PARADOX}

En sak återstår nu för att fullborda cirkeln. Jag skall behandla Albertis ambivalenta användning av uttrycket "centrumlinjen". Det verkar som om Alberti med denna retoriska gest projicerat ut centrumpunkten på bildens horisontlinje, så att denna punkt inte längre skärs av cirkeldiametern, utan av cirkelns periferi. Samtidigt ser vi på den centralperspeiktiviska bilden att målaren ofta väljer att redovisa ett antal flyktlinjer, som löper samman mot den punkt där centrumstrålen träffar bildytan. På bilden fyller centrumpunkten funktionen att samla upp linjer vilka försvinner mot bildjupet men redovisas som ett solfjädermönster på bildens yta. I vilken mening kan vi vara säkra på centrumpuniktens placering? Det beror på hur bilden tolkas. Ser vi den som en platt yta ligger centrumpunkten på denna yta i mitten av ett solfjädersmönster. Men ser vi bilden som genomskinlig blir tolkningsmöjligheterna flera, i själva verket oändligt många, vilket påpekats redan av Vitruvius och som utretts av Ernst Gombrich i kapitlet "Ambiguities of the Third Dimension" i Art and Illusion. 41 I dessa tolkningar kan flyktpunkten placeras olika långt in $\mathrm{i}$ bilden, vid horisonten fjorton kilometer bort, i oändligheten, eller var som helst mellan bildplanet och oändligheten. En $i$ detta sammanhang aktuell diskussion av en. passage $\mathrm{i}$ Vitruvius första bok om arkitekturen återfinner vi i Panofskys Perspektivet som symbolisk form och jag använder mig även här av Sölve Olssons svenska översättning. Panofsky resonerar kring Vitruvius definition att "scenographia" "(det vill säga den perspektiviska framställningen av något på en plan yta) grundar sig på "omnium linearum ad circini centrum responsus". Panofsky tolkar denna definition som att den utesluter att scenographian skulle -beteckna en centralperspektivisk bildkonvention: "Ögonpunkten" i det moderna centralperspektivet kan på intet sätt betecknas som "circini centrum" (egentligen passarspets ["Zirkelspitze", i originalet ${ }^{42}$ ] oegentligt "mittpunkt i en cirkel") eftersom den enbart är konvergenspunkt för ortogonalerna och inte ger någon som helst anledning att använda en passare."43 Detta är ett påstående

41 E. H. Gombrich, Art and Illasion: A Study in the Psycbology of Pictorial Representation. The A. W. Mellon Lectures in the Fine Arts, 1956. 4th ed., (Princeton, New Jersey: Princeton Univ. Press, 1972); Kap VII, avsnitt III, IV.

42 Erwin Panofsky, "Die Perspektive als 'symbolische Form", Vorträge der Bibliotbek Warburg 4 (1924-25), 266.

43 Panofsky, Perspektivet som symbolisk form, övers. Sölve Olsson, (Stockholm: Symposion, 1994), 44. 
som är falskt om min demonstration av Albertis flyktpunktsresonemang är riktig. ${ }^{44}$ För Alberti tyclss det vara enklare än för Panofsky att jämställa ett "utanför bilden liggande projektionscentrumn som representerar det betraktande ögat" med bildens centrumpunkt.45 Vilka slutsatser man i övrigt kan dra av denna jämförelse, så torde den i alla klargöra att det finns en stark relation mellan Vitruvius formulering och det som ter sig som ett försök av Alberti att upplösa en förtätad formulering i möjliga argument.

I vissa avseenden tycks denna uppställning ge oväntat stöd åt en Albertiläsning som går på tvärs mot Marcussens tolkning av Albertis traktat. Bryson skriver angående centrumpunktens axiala projicering som en centralstråle:

/B/ecause the Albertian concept of the centric ray - the line between the viewpoint and the vanishing point - is axial, the viewer proposed and assumed by the image is in fact given no single point from which the image is to be seen. 40

Något senare fortsätter han:

In its production of the centric ray between viewpoint and vanishing point, the Albertian regime assumes the viewer not simply as an ambient witness $/ . . . /$, but as a physical presence; and in this sense the vanishing point is the anchor of a system which incarnates the viewer, renders him tangible and corporeal, a measurable, and above all a visible object in a world of absolute visibility. The centric ray constitutes a return of the gaze upon itself: the cone of rays emanating from the Albertian eye is redoubled in its opposite, a cone radiating towards it out of that point from which all the architectonic lines radiate: in the Raphael, from the blank opening at the centre of the temple. At the picture plane, the two cones intersect; which is to say that the single vanishing point marks the installation within the painting of a principle of radical alterity, since its gaze returns that of the viewer as its own object: something is looking at my looking: a gaze whose position I can newer occupy, and whose vista I can imagine only by reversing my own, by inverting the perspective before me, and by imagining my own gaze as the new, palindromic point of disappearance on the horizon. ${ }^{47}$

Det här citerade stället är fullt av svårtydda påståenden och jạg opponerade mig som C-student mot tanken på en perspektivstrut inne i bilden. På den punkten har jag fătt anledning att ändra mig. Hubert Damisch resonemang i The Origin.

44 Jag inleder med att citera Alberti, Om målarkonsten, \$6 "Ögat mäter med dessa strålar som med benen på en passare." Motsvarande sats på latin i "De Pictura" lyder: "quod oculus quasi circino quodam instrumento his axtremis radiis metitur."

45 Panofsky, Perspektivet som symbolisk form, 46. Panofsky, "Die Perspektive als 'symbolische Form'", 266.

46 Bryson, 104.

47 Ibid., 106. 
of Perspective demonstrerade tydligt för mig att betraktaren av en bild (jag som läsare likaväl som författaren själv) har en naturlig tendens att trycka ihop bildrummet i djupled under vissa omständigheter. ${ }^{48}$ Denna undersökning av några olika uppfattningar och upplagor av Albertis text har lett mig till att respektera Brysons uppfattning av Alberti. Jag lutar nog åt att den som i detta avseende förhåller sig mest "digteriskt" till historien är Marcussen och inte Bryson. I andra avseenden sympatiserar jag annars med hennes uppfattning. Det är något jag skall återkomma till i ett annat sammanhang.

48 Hubert Damisch, The Origin of Perspective, eng. övers. John Goodman (Cambridge, Mass.: MTT Press, 1994), 371. 